\title{
Review Article \\ Status, Alert System, and Prediction of Cyanobacterial Bloom in South Korea
}

\author{
Ankita Srivastava, ${ }^{1}$ Chi-Yong Ahn, ${ }^{1}$ Ravi Kumar Asthana, ${ }^{2}$ \\ Hyung-Gwan Lee, ${ }^{1}$ and Hee-Mock $\mathrm{Oh}^{1}$ \\ ${ }^{1}$ Environmental Biotechnology Research Center, Korea Research Institute of Bioscience and Biotechnology, \\ Daejeon 305-806, Republic of Korea \\ ${ }^{2}$ Centre of Advanced Study in Botany, Banaras Hindu University, Varanasi 221 005, India \\ Correspondence should be addressed to Hee-Mock Oh; heemock@kribb.re.kr
}

Received 2 August 2014; Revised 5 November 2014; Accepted 5 November 2014

Academic Editor: Saulius Butenas

Copyright (C) 2015 Ankita Srivastava et al. This is an open access article distributed under the Creative Commons Attribution License, which permits unrestricted use, distribution, and reproduction in any medium, provided the original work is properly cited.

\begin{abstract}
Bloom-forming freshwater cyanobacterial genera pose a major ecological problem due to their ability to produce toxins and other bioactive compounds, which can have important implications in illnesses of humans and livestock. Cyanobacteria such as Microcystis, Anabaena, Oscillatoria, Phormidium, and Aphanizomenon species producing microcystins and anatoxin-a have been predominantly documented from most South Korean lakes and reservoirs. With the increase in frequency of such blooms, various monitoring approaches, treatment processes, and prediction models have been developed in due course. In this paper we review the field studies and current knowledge on toxin producing cyanobacterial species and ecological variables that regulate toxin production and bloom formation in major rivers (Han, Geum, Nakdong, and Yeongsan) and reservoirs in South Korea. In addition, development of new, fast, and high-throughput techniques for effective monitoring is also discussed with cyanobacterial bloom advisory practices, current management strategies, and their implications in South Korean freshwater bodies.
\end{abstract}

\section{Introduction}

Cyanobacteria can form dense blooms, scums, and mats that hamper the quality of water. Cyanobacterial genera like Anabaena, Aphanizomenon, Cylindrospermopsis, Lyngbya, Microcystis, Oscillatoria, Nodularia, and Nostoc are known to produce a wide variety of toxic compounds [1]. There have been increasing reports of cyanobacterial toxins and toxigenic species worldwide. Environmental factors that influence cyanobacteria dominance are well studied but the abundance of cyanobacteria varies with habitats as well as the environmental regimes. Favorable conditions for a cyanobacterial bloom include light, temperature, nutrients (mainly $\mathrm{N}$ and $\mathrm{P}$ ), and quiescent water [2]. Eutrophication has been cited as a major cause of increasing cyanobacterial harmful algal blooms [3] and is also a widely recognized problem in South Korea $[4,5]$. Four major rivers like Han, Geum, Nakdong, and Yeongsan in South Korea (Figure 1) are also suffering from cyanobacterial blooms. The Han River is the largest river system located in the central region and the Nakdong River is the second largest river system located in the southeastern part of the Korean peninsula. The Han River is the main water resource for the Seoul metropolitan area while the Nakdong River supplies water to Busan and Daegu, the second and third biggest cities, respectively. The water quality is deteriorated in the midstream and downstream regions where most of the population and major industries are located. The Geum River watershed and the Yeongsan River watershed are in the western part of the country. Most of the studies have focused on Daechung Reservoir which is located upstream of the Geum River and is the source of residential, agricultural, and industrial purposes.

In its Green Vision 21 river quality, 114 rivers and streams located in the four major basins of the Han, Nakdong, Geum, and Yeongsan were assigned Class I (i.e., best quality to 36 catchments) and Class II (46 catchments) quality. This grading system is based on variables such as biochemical oxygen demand (BOD), pH, suspended solids (SS), dissolved 


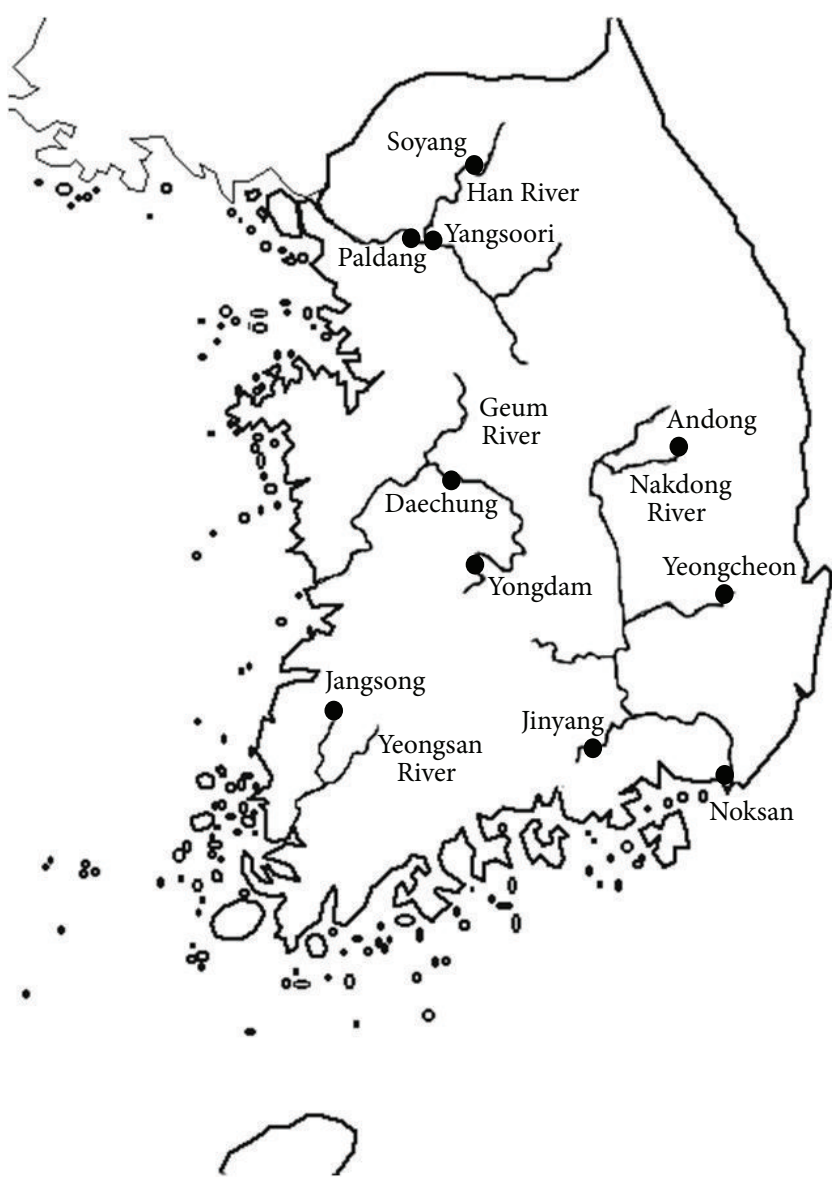

FIgURE 1: Map showing the location of four major rivers in South Korea.

oxygen (DO), total phosphorus and nitrogen, and total $E$. coli count.

Authorities responsible for water resources planning and management are often faced with problems of determining policy in accordance with a future climate change. Ministry of Environment started a national survey for streams and rivers health evaluation project in 2007 with a task of monitoring of stream sites for periphyton, benthic macroinvertebrates, fish, and riparian characteristics [6]. Recently, algal blooms caused a major scare over the quality of the country's drinking water. The Nakdong River and Han River were affected more seriously, which supply water to major cities in South Korea [7]. Long heat wave, drought, and plenty of sunlight with high levels of nutrients were reported as the main causes of blooms by the South Korean government.

Over the years, various field studies have been conducted for understanding the diverse interactions among physicochemical and biological variables leading to the proliferation of cyanobacterial blooms in Korean freshwater bodies [8, 9]. Furthermore, several monitoring approaches and predictive models were developed to provide accurate and timely information regarding the development of cyanobacterial bloom in the water bodies $[10,11]$. Lee et al. [12] summarized various techniques that have been adopted for the control and mitigation of algal blooms in South Korea. This review presents the advances in the understanding of the occurrence and toxicity of cyanobacterial blooms in South Korean water bodies. Development of new, high-throughput techniques for effective monitoring, cyanobacterial bloom advisory practices, predictive models, and current management strategies are also discussed here.

\section{Field Studies regarding Cyanobacterial Blooms in South Korea}

South Korea relies on rivers and streams for water supply due to lack of reliable groundwater sources. Four major rivers (Han, Nakdong, Geum, and Yeongsan) meet the needs of more than 40 million residents. The induction of the growth and development of cyanobacterial blooms are regulated by various environmental factors [20]. Therefore, many researchers have focused on the detailed study of these factors and natural variability of toxins concentrations in various Korean reservoirs (Table 1 ).

Distribution of dominant species of cyanobacteria and the amount of hepatotoxic microcystins (MCs) and neurotoxic anatoxin-a in cyanobacterial blooms were investigated in 12 Korean lakes during 1992-1995 [13]. Six species each of Microcystis and Anabaena and two of Oscillatoria with percent dominance of 60,30 , and $10 \%$, respectively, were identified in these lakes. MCs were identified as the main toxin and anatoxin-a was also reported for the first time from freshwater sources in South Korea. In another study, trophic status of ten reservoirs in the upstream and middle stream regions and three estuarine reservoirs was evaluated from 1993 to 1994 and from 1994 to 1995, respectively [21]. A seasonal variation in the pattern of phytoplankton standing crop was observed with higher density occurring in the estuarine reservoirs than deep upstream reservoirs due to high nutrient concentrations and seasonal changes in hydrology. Differences in the timing of succession were also reported in these reservoirs. Diatoms like Asterionella and Aulacoseira were dominant in spring (in deep reservoirs) and winter (in shallow reservoirs) while cyanobacteria (mostly Microcystis) appeared in estuarine reservoirs in warm seasons when there was a drought.

Various studies have focused on water quality, algal community composition, toxin production, short-term prediction of algal blooms, and variations in the environmental factors in the Daechung Reservoir [22-25]. In a study by Oh et al. [16], physico- and biochemical processes, along with changes in MC concentration, were monitored during the period of cyanobacterial blooms in Daechung Reservoir. Since MC analysis is important for determining the safety of water resources, an indirect monitoring method was proposed for estimating their concentrations in eutrophic waters based on phytoplankton number, chlorophyll- $a$ (Chl $a$ ) concentration, and the ratio of the particulate and the dissolved forms of nitrogen $(\mathrm{N})$ and phosphorus $(\mathrm{P})$. The ratio of particulate to dissolved $\mathrm{N}$ or $\mathrm{P}$ at 0.6 could be used as a threshold for determining the $\mathrm{MC}$ concentration. The MC concentration also varied with the particulate $\mathrm{N} / \mathrm{P}$ ratio. It was less than $50 \mathrm{ng} / \mathrm{L}$ at a particulate N/P ratio $<8$, whereas it varied substantially at higher ratios. Relationship between anatoxin-a 
TABLE 1: Toxins concentrations reported from various freshwater bodies in South Korea.

\begin{tabular}{|c|c|c|c|c|}
\hline $\begin{array}{l}\text { Dominant } \\
\text { cyanobacteria } \\
\text { genus }\end{array}$ & Toxins $(\mu \mathrm{g} / \mathrm{g}$ or $\mu \mathrm{g} / \mathrm{L})$ & Reservoir (river) & Sampling date & Reference \\
\hline Microcystis & $133(\mu \mathrm{g} / \mathrm{g}, \mathrm{MC})$ & Soyang (Han River) & 26 Oct. 1992 & \multirow{4}{*}[13]{} \\
\hline Oscillatoria & 76 & Daechung (Geum River) & 06 Oct. 1992 & \\
\hline Anabaena & 115 & Jangsong (Yeongsan River) & 15 Oct. 1994 & \\
\hline (algal samples) & 635 & Noksan (Nakdong River) & 27 Aug. 1995 & \\
\hline $\begin{array}{l}\text { Microcystis } \\
\text { (algal samples) }\end{array}$ & $288-2612(\mu \mathrm{g} / \mathrm{g}, \mathrm{MC})$ & 10 large reservoirs & Aug. 1996-Oct. 1997 & {$[14]$} \\
\hline Microcystis & $\begin{array}{c}1.89 \mu \mathrm{g} / \mathrm{L} \text { except at } \\
\text { Site } 1(19.1 \mu \mathrm{g} / \mathrm{L})\end{array}$ & $\begin{array}{l}\text { Noksan Station } \\
\text { (Nakdong River) }\end{array}$ & 20 Aug. 1998 & {$[15]$} \\
\hline Microcystis & $0.057-0.488(\mu \mathrm{g} / \mathrm{L}, \mathrm{MC})$ & $\begin{array}{c}\text { Paldang } \\
\text { (Han River) }\end{array}$ & 03 Sep.-28 Nov. 1997 & {$[8]$} \\
\hline Microcystis & $0.2(\mu \mathrm{g} / \mathrm{L}, \mathrm{MC})$ & $\begin{array}{c}\text { Daechung } \\
\text { (Geum River) }\end{array}$ & 27 Apr.-12 Oct. 1999 & {$[16]$} \\
\hline $\begin{array}{l}\text { Anabaena } \\
\text { Oscillatoria }\end{array}$ & $0.01-0.08(\mu \mathrm{g} / \mathrm{L}, \mathrm{AT})$ & $\begin{array}{c}\text { Daechung } \\
\text { (Geum River) }\end{array}$ & 18 Jun.-5 Nov. 2001 & {$[17]$} \\
\hline Microcystis & $\begin{array}{l}0.59(\mu \mathrm{g} / \mathrm{L}, \mathrm{MC}) \\
0.55(\mu \mathrm{g} / \mathrm{L}, \mathrm{MC})\end{array}$ & $\begin{array}{c}\text { Yangsoori } \\
\text { Seokchon } \\
\text { (Han River) }\end{array}$ & 2-3 Oct. 2004 & {$[18]$} \\
\hline
\end{tabular}

MC: microcystin, AT: anatoxin-a.

production and environmental factors was also analyzed in the reservoir [17]. Anatoxin-a was mainly produced by Anabaena sp. and Oscillatoria sp. and found to be highly correlated with $\mathrm{N}: \mathrm{P}$ ratio. The magnitude and duration of rainfall also played an important role in determining the extent of cyanobacterial blooms in the Daechung Reservoir. The major species and relative abundance of cyanobacteria varied depending on the climatic conditions $[26,27]$. The composition and dynamics of cyanobacteria during bloom were further elucidated using molecular-based techniques. Various genes, for example, $16 \mathrm{~S}$ rRNA, internal transcribed spacer (ITS), and phycocyanin intergenic spacer (PC-IGS), were used for analyzing cyanobacterial diversity [28] and for characterizing toxic and nontoxic Microcystis colonies in natural populations $[9,29]$. The ratio of toxigenic Microcystis sp. to that of total Microcystis sp. ranged from 7.6 to $56.6 \%$ and the proportion changes of potentially toxic Microcystis genotypes were more closely related with water temperature [9].

Ha et al. [30,31] have shown the importance of flow regulation of dams on the proliferation and succession pattern of phytoplankton in the lower Nakdong River. Horizontal and vertical distributions of MCs were also examined for the first time across the width of the Noksan Station in the Nakdong River [15]. Bloom samples from this site were dominated by $M$. aeruginosa with MC-RR as the dominant variant. Spatial and temporal dynamics of phytoplankton communities was also studied in the Nakdong River. Small centric and pennate diatoms dominated from winter to early spring. A mixed community of cryptomonads, diatoms, and coenobial greens such as Pediastrum and Scenedesmus were dominant in late spring (May-June) while blue-green algae like Anabaena, Microcystis, and Oscillatoria dominated in summer (JulySeptember). The role of hydrological changes was discussed as the main driving factor for phytoplankton succession as there was little fluctuation in the dominant phytoplankton even when the nutrient concentration varied in each study site [31]. It was concluded that the high loading of nutrients, the flow regulation by dams, and the estuarine barrage were responsible for bloom formations. In another study, data on the limnological parameters and phytoplankton population were collected over a long period of time (19932001) to investigate the relationship between dam hydrology and phytoplankton proliferations in the river [32]. Two phytoplankton species, M. aeruginosa and Stephanodiscus hantzschii, changed dynamically with dam hydrology during summer and winter, respectively, and the peaks of both species were observed when discharge persisted at low level. The authors argued that "smart flow control," that is, more precise control of dam discharge during summer and winter, could prevent the bloom formation by the two species in the river systems and increase the efficiency of water resource management system.

Many dams have been constructed along the Han River for flood control, water supply, and hydropower generation. Fluctuations in the phytoplankton communities due to dam discharge have also been reported [33]. Recently, the effects of sampling periods and environmental factors on cyanobacterial communities at 6 sites along the Nakdong River were investigated in detail [34]. High-throughput sequencing of cyanobacterial $16 \mathrm{~S}$ rRNA revealed a total of 175 cyanobacterial genera where cyanobacterial communities varied from June to September. Prochlorococcus was predominant in May, whereas the relative abundance of Microcystis and Anabaena increased with increase in water temperature. This shift in communities was mainly influenced by site location, nitrogen, and phosphorus. 
TABLE 2: Alert levels framework for algal bloom in South Korea.

\begin{tabular}{lccc}
\hline Level & Caution & Warning & Outbreak \\
\hline Chlorophyll- $a(\mu \mathrm{g} / \mathrm{L})$ & $\geq 15$ & $\geq 25$ & $\geq 100$ \\
Cyanobacteria $($ cells $/ \mathrm{mL})$ & $\geq 500$ & $\geq 5,000$ & $\geq 1,000,000$ \\
Monitoring interval $(/$ week $)$ & 1 & 2 & 2 \\
\hline
\end{tabular}

\section{Monitoring Approaches}

An important goal of monitoring approach is the timely prediction of blooms events and therefore depends on various aspects such as flexibility, types of water bodies, dominant species, and sampling methods and time. Different sampling practices can influence the timely prediction of blooms and thus necessitate the development of a standardized procedure for sample collection. In a study by Ahn et al. [35], different sampling methods (pumping, integrating, Van Dorn, inflow, and mixing) and times were compared which revealed the integrating method as the most suitable one for sampling both Microcystis and Oscillatoria. In addition, the median and median absolute deviation (MAD) was proposed as a method to express a central tendency for cyanobacterial biomass.

Generally, microscopic identification and cell counting are the basic techniques for monitoring a cyanobacterial bloom. Various methods (boiling, vortexing, sonication, and $\mathrm{TiO}_{2}$ treatments) were compared for making single cell suspension of Microcystis colonies [36]. In this study, boiling was found to be the most suitable and effective method for generating free cells from colonies. Nutrients like $\mathrm{N}$ and $\mathrm{P}$ and their ratios were already reported to be reliable indicators of blooms in the Daechung Reservoir and are considered valuable in assessing the potential for future bloom development [37]. Later, $\mathrm{K}$ and Fe ratio was also proposed as a new parameter for predicting a bloom in the reservoir that was dominated by Microcystis sp. [38]. It was suggested that a threshold ratio (200) of $\mathrm{K}$ and Fe would reflect the same type of bloom as that with a cyanobacterial concentration of 20,000 cells/mL [39] and phycocyanin (PC) concentration of $20 \mathrm{pM}$ [37].

World Health Organization (WHO) has established a drinking water standard of $1 \mu \mathrm{g} / \mathrm{L}$ for MC-LR and developed provisional guidelines as follows: Level 1 (low health risk probability): 20,000 cyanobacterial cells $/ \mathrm{mL}$ or $10 \mu \mathrm{g} / \mathrm{L} \mathrm{Chl}$ $a$ with dominance of cyanobacteria, Level 2 (moderate possibility of adverse health effects): 100,000 cells $/ \mathrm{mL}$ or $50 \mu \mathrm{g} / \mathrm{L}$ Chl $a$, and Level 3 (high health risk probability): formation of cyanobacterial scums [40,41]. The Australian Drinking Water Guidelines, published jointly by the National Health and Medical Research Council and National Resource Management Ministerial Council, provide the frameworks for management of cyanobacteria and cyanotoxins in Australian water bodies [42]. Assuming the toxic cyanobacteria as the main bloom formers, an alert system for algal bloom was developed by the Ministry of Environment (South Korea) in 1997 (Table 2) [27] and since then has declared days of "caution/warning" at 3 sites in Daechung Reservoir during 1997-2013 (Figure 2) and in major Korean reservoirs (Table 3 ). The sequence of alert levels is based upon measurement of Chl $a$ and cyanobacterial cell density (combined total of Anabaena, Aphanizomenon, Microcystis, and Oscillatoria). The alert is declared when Chl $a$ and cyanobacterial cell density exceed the criteria consecutively two times. The analysis frequency is once per week which can be increased to over 2 times at "warning" and "outbreak." Moreover, the alert is stepped down or cancelled if the Chl $a$ level reaches below $15 \mu \mathrm{g} / \mathrm{L}$ or cyanobacterial cell density is below 500 cells $/ \mathrm{mL}$. PC is a function of cyanobacterial biomass only, and its measurement seems to be a practical approach over that of $\mathrm{Chl} a$. Therefore, an alternative cyanobacterial alert system based on PC level was suggested to monitor Microcystis bloom in Korean lakes [43]. This was based on PC levels of 0.1 (caution), 30 (warning), and $700 \mu \mathrm{g} / \mathrm{L}$ (outbreak), respectively, and corresponded with the new suggested criteria of Chl $a$ concentrations (3, 30 and $100 \mu \mathrm{g} / \mathrm{L})$ and cyanobacterial cell density $(1,000,10,000$, and 100,000 cells $/ \mathrm{mL})$. In another study, a criterion of $10,000,20,000,40,000$, and 80,000 cells $/ \mathrm{mL}$ was also proposed for specific cyanobacteria like Microcystis, Oscillatoria, Anabaena, and Aphanizomenon spp., respectively. However, this was based on the cell numbers and cellular MCs content of cyanobacteria, which were collected from several Korean lakes and rivers [44].

\section{Models for Prediction of Cyanobacterial Blooms}

Community dynamics is often regulated by complex and diverse ecological parameters making it difficult to identify the underlying ecosystem mechanisms. Development of ecological models and computational technologies over the years has made the prediction of algal blooms more accurate. Various deductive and computational inductive models have been used for ecological modeling $[45,46]$. Inductive models like artificial neuron networks (ANNs) have been widely used to forecast the occurrence of cyanobacterial blooms in reservoirs due to their better predictive power and its ability to map the nonlinear relationship between variables of the ecosystem [47]. ANN basically consists of interconnected processing elements having inputs that are multiplied by weights (strength of the respective signals) and an output layer. The weights of an artificial neuron can be adjusted using algorithms in order to obtain the desired output from the network. This process of adjusting the weights is called learning or training [48]. Backpropagation is the most common algorithm in which the signals are sent forward and the errors are propagated backwards. Multilayer perceptron (MLP) is a supervised learning algorithm having input, hidden layer(s) and an output layer. MLP with a backpropagation model has already been applied to predict the seasonal variations and the magnitude of bloom in South Korean water bodies. Environmental stressors and water quality indices can be checked with the use of an unsupervised learning algorithm like self-organizing maps (SOMs) which consists of an input and output layer.

Oh et al. [49] used these models for patterning algal communities and key factors causing bloom in Daechung Reservoir (located upstream of the Geum River) based on the 3-year data. These models were further used to explore 


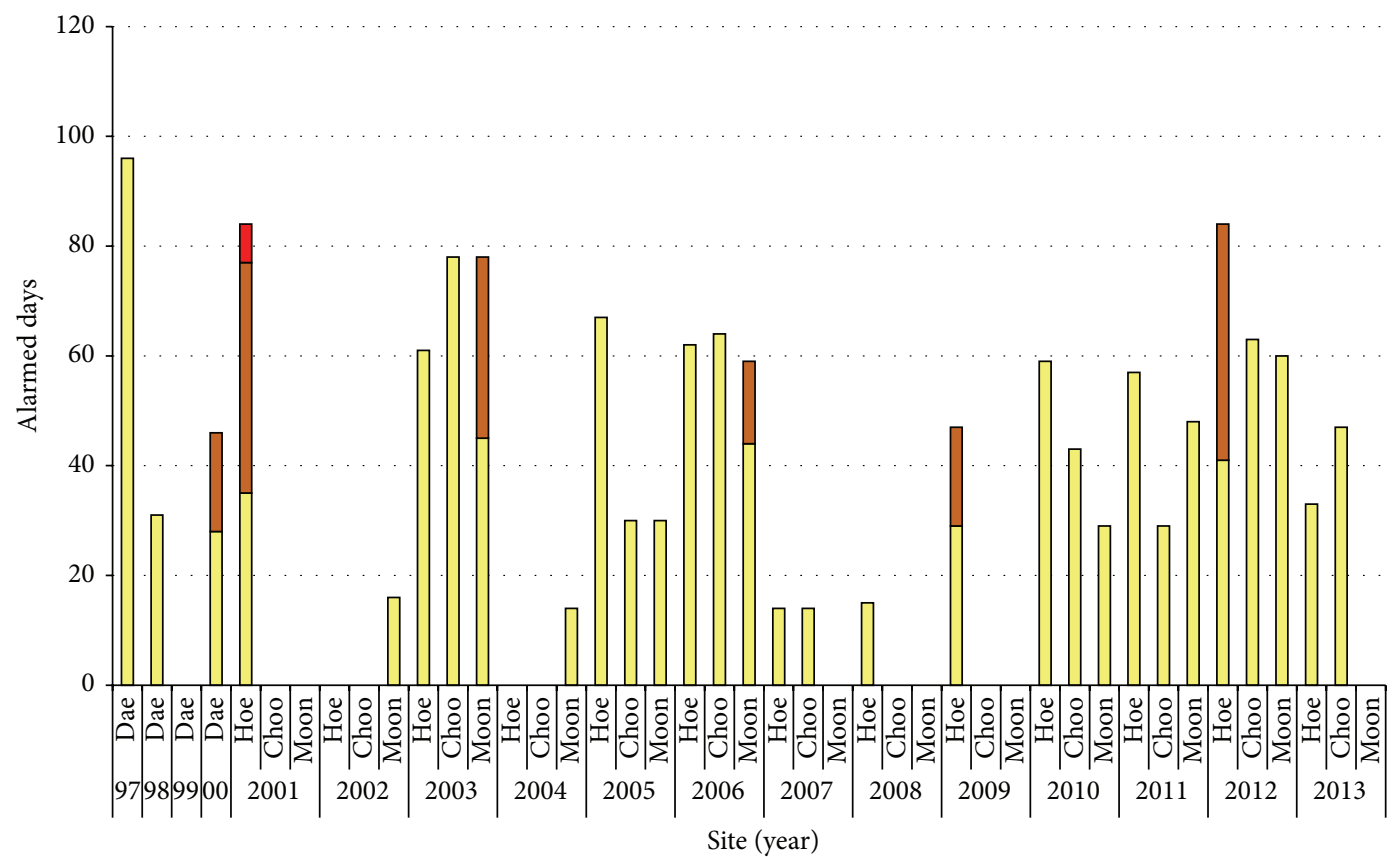

Outbreak

Warning

Caution

Figure 2: Alarmed days declared at 3 sites in Daechung Reservoir during 1997-2013, where Dae: Daechung Reservoir, Hoe: Hoenam, Choo: Choodong, and Moon: Moonue.

TABLE 3: Days of "caution (warning)" declared in major Korean reservoirs (Ministry of Environment, [19]).

\begin{tabular}{|c|c|c|c|c|c|c|c|c|c|c|c|}
\hline \multirow{2}{*}{ Reservoir } & \multicolumn{11}{|c|}{ Year } \\
\hline & ’02 & ’03 & '04 & ’05 & ’06 & '07 & ’08 & ’09 & '10 & '11 & '12 \\
\hline Sum & 93 & $166(33)$ & 97 & 318 & $311(34)$ & $198(97)$ & 114 (19) & $244(43)$ & $177(14)$ & 131 & $161(43)$ \\
\hline Han River & - & - & - & - & 31 & - & 11 & - & - & - & 14 \\
\hline Paldang & 20 & - & 14 & 15 & 21 & - & 36 & 23 & 43 & - & 28 \\
\hline Gwanggyo & - & - & - & - & - & 12 & - & - & - & - & 35 \\
\hline Unmun & - & - & - & - & - & - & - & - & - & 16 & - \\
\hline Daechung & 16 & $90(33)$ & 14 & 67 & $78(15)$ & 14 & 15 & $47(18)$ & 59 & 57 & $84(43)$ \\
\hline Yongdam & - & - & - & 80 & 38 & - & - & - & 19 & - & - \\
\hline Boryeong & - & - & - & - & - & - & - & - & $19(14)$ & - & - \\
\hline Yeongcheon & - & - & 40 & 86 & $100(19)$ & $139(97)$ & $37(19)$ & - & - & 36 & - \\
\hline Juam & 57 & 76 & 14 & - & - & 19 & - & $41(25)$ & 37 & - & - \\
\hline Dongbok & - & - & 15 & - & - & 14 & - & 41 & - & - & - \\
\hline Jinyang & - & - & - & 17 & - & - & 15 & 51 & - & - & - \\
\hline Deokdong & - & - & - & - & - & - & - & - & - & 22 & - \\
\hline Angye & - & - & - & 53 & 43 & - & - & - & - & - & - \\
\hline Hoeya & - & - & - & - & - & - & - & 41 & - & - & - \\
\hline
\end{tabular}

the temporal shifts in environmental parameters and for predicting bloom peak in the reservoir [50]. Among the various environmental factors, water temperature and total dissolved nitrogen were found to be the major determinants for cyanobacteria and Microcystis bloom could be predicted 3 weeks earlier. The findings of this study also corresponded well with the alert system for prediction of cyanobacterial bloom in South Korea [27]. Although it is difficult to decide on the best training algorithm and the number of hidden layer nodes, its advantages lie in that it requires no information on the model structure and developed models were more flexible and adaptable to alternative scenarios [48]. 
Evolutionary algorithms (EAs) are another branch of machine learning techniques based on the principle of biological evolution, such as crossover, mutation, and chromosome's alteration, and are used to predict and elucidate specific ecological phenomena [51]. Various predictive models for algal blooms have also been developed and applied to the second largest river in South Korea (Nakdong River) $[52,53]$. This is a eutrophic regulated river system with several multipurpose dams and is often faced with cyanobacterial blooms in the summer. A water quality model based on the USEPA's QUAL2E was also developed for management of large river systems [52]. Inclusion of some parameters like DO, BOD, nitrogen, and phosphorus in the model resulted in better agreement with the field measurements due to its ability to simulate the conversion of algal death to BOD, fixed plant DO, and the denitrification. Jeong et al. [53] modeled M. aeruginosa bloom dynamics using evolutionary computation with 25 limnological parameters. A nonlinear plankton model was developed that predicted daily abundance of phytoplankton species and the influence of environmental parameters was quantitatively analyzed [51]. They suggested that the relationship between river hydrology and phytoplankton dynamics should be explored over a longer period of time and water physicochemistry such as $\mathrm{pH}$, temperature, and some nutrients played important roles in governing the daily changes of the two species $(M$. aeruginosa and $S$. hantzschii). Equation models based on a genetic programming (GP) algorithm and multiple linear regression (MLR) were used for predicting the temporal dynamics and magnitude of blooms. Although MLR failed to predict the bloom accurately, this study demonstrated that an inductive approach is more suitable for modeling the dynamics of algal blooms in a river-reservoir system. Later community changes of cyanobacteria were used to identify patterns in the eutrophication process of the river, revealing the seasonal occurrence of Anabaena bloom in spring and summer [10].

Two algorithms, an algebraic function model and a rulebased model, were developed with an aim to model the abundances of $M$. aeruginosa in Nakdong [54]. The rulebased model correctly predicted the timing and abundance of Microcystis on the basis of 8 years of limnological data from the lower Nakdong River. Sensitivity analysis basically provides useful information about the significant input variables and their relationship with each other and this study demonstrated high water temperature as the important parameter influencing the abundances of $M$. aeruginosa. Recently, SOM was used in river basin patterning and large sets of catchmentwise data (1655 stream sites) were explored in the Nakdong River to reveal stream modification patterns [55]. Stream Modification Index (SMI) system was developed for this purpose and the degree of stream modification was approximately related with sociogeographical aspects. The results of this survey provided an insight into the morphological characterization and status of streams or rivers in the river basin.

More recently, Cha et al. [11] developed a Bayesian hurdle Poisson model based on the data from 2007 to 2011 to predict cyanobacterial bloom in Lake Paldang. The model predictions demonstrated that the principal factor that determines the success of cyanobacteria was temperature. High temperature and a stable water column were demonstrated as main factors required for high abundance of cyanobacteria. This model can be used to forecast cyanobacteria and for the development of mitigation strategies of cyanobacterial blooms.

\section{Conclusion}

Reservoirs and regulated rivers are the major sources of freshwater in South Korea. Various field studies have been done and technical approaches have been adopted to solve the nationwide problem of cyanobacterial blooms. The phytoplankton community shows seasonal variation in most of the reservoirs and has been related to temperature, nutrients like $\mathrm{P}$, and changes in hydrology. Microcystis, Anabaena, and Oscillatoria have been predominantly documented from most South Korean reservoirs. However, cyanobacterial growth and dispersal could be studied in relation to land use and climate change. Furthermore, monitoring techniques and alert systems have also been developed for the timely prediction and management of cyanobacterial blooms. However, inclusion of other parameters like PC as an alert criterion can prove useful for efficient monitoring. The levels of cyanotoxins especially MCs are reported to be below the WHO limit of $1 \mu \mathrm{g} / \mathrm{L}$ in most of the reservoirs and till now there is no data on human health hazards due to exposure to toxic cyanobacterial blooms in South Korea. However, a standard for cyanobacterial biomass and selected cyanotoxins would be important in the context of development of management strategies and water safety plan.

\section{Conflict of Interests}

The authors declare that there is no conflict of interests.

\section{Acknowledgments}

This research was supported by grants from the KIST Institutional Program (Project no. 2E24280) and the R\&D Program for Society of the National Research Foundation (NRF) funded by the Ministry of Science, ICT and Future Planning (Grant no. 2014M3C8A4030437). Ravi Kumar Asthana is thankful to UGC (University Grants Commission) and UPE support from the university, for financial support.

\section{References}

[1] W. W. Carmichael, "Health effects of toxin-producing cyanobacteria: "the CyanoHABs"', Human and Ecological Risk Assessment, vol. 7, no. 5, pp. 1393-1407, 2001.

[2] H. K. Hudnell and Q. Dortch, "A synopsis of research needs identified at the interagency, international symposium on cyanobacterial harmful algal blooms (ISOC-HAB)," in Cyanobacterial Harmful Algal Blooms: State of the Science and Research Needs, H. K. Hudnell, Ed., chapter 2, p. 950, Springer, New York, NY, USA, 2008.

[3] H. W. Paerl and J. Huisman, "Blooms like it hot," Science, vol. 320, no. 5872, pp. 57-58, 2008. 
[4] B. Kim, D.-S. Kim, and O.-K. Kwon, "The trophic state of Lake Paldang," Journal of Korean Society on Water Quality, vol. 5, no. 2, pp. 39-46, 1989.

[5] H.-W. Kim, K. Ha, and G.-J. Joo, "Eutrophication of the lower Nakdong River after the construction of an estuarine dam in 1987," International Review of Hydrobiology, vol. 83, pp. 65-72, 1998.

[6] National Institute of Environmental Research, Survey and Evaluation of Aquatic Ecosystem Health: The Nakdong River Basin, National Institute of Environmental Research, Incheon, Korea, 2008.

[7] S.-B. Park, "Algal blooms hit South Korean rivers," Nature News, 2012.

[8] H.-K. Park, W.-H. Jheong, O.-S. Kwon, and J.-K. Ryu, "Seasonal succession of toxic cyanobacteria and microcystins concentration in Paldang Reservoir," Algae, vol. 15, no. 1, pp. 29-35, 2000.

[9] S.-H. Joung, H.-M. Oh, S.-R. Ko, and C.-Y. Ahn, "Correlations between environmental factors and toxic and non-toxic Microcystis dynamics during bloom in Daechung Reservoir, Korea," Harmful Algae, vol. 10, no. 2, pp. 188-193, 2011.

[10] G.-J. Joo and K.-S. Jeong, "Modelling community changes of cyanobacteria in a flow regulated river (the lower Nakdong River, S. Korea) by means of a self-organizing map (SOM)," in Modelling Community Structure in Freshwater Ecosystems, S. Lek, M. Scardi, P. Verdonschot, J. P. Descy, and Y. S. Park, Eds., pp. 273-287, Springer, Berlin, Germany, 2005.

[11] Y. Cha, S. S. Park, K. Kim, M. Byeon, and C. A. Stow, "Probabilistic prediction of cyanobacteria abundance in a Korean reservoir using a Bayesian Poisson model," Water Resources Research, vol. 50, no. 3, pp. 2518-2532, 2014.

[12] C. S. Lee, C.-Y. Ahn, H.-J. La, S. Lee, and H.-M. Oh, “Technical and strategic approach for the control of cyanobacterial bloom in fresh waters," Korean Journal of Environmental Biology, vol. 31, no. 4, pp. 233-242, 2013.

[13] H. D. Park, B. Kim, E. Kim, and T. Okino, "Hepatotoxic microcystins and neurotoxic anatoxin-a in cyanobacterial blooms from Korean lakes," Environmental Toxicology and Water Quality, vol. 13, no. 3, pp. 225-234, 1998.

[14] B. Kim, H.-S. Kim, H.-D. Park, K. Choi, and J.-G. Park, "Microcystin content of cyanobacterial cells in Korean reservoirs and their toxicity," Korean Journal of Limnology, vol. 32, no. 4, pp. 288-294, 1999.

[15] V. C. Srivastava, A. R. Choi, W. Kim, and J. A. Lee, "Horizontal and vertical distribution of protein phosphatase inhibitors of microcystin class in the Naktong River, Korea," Algae, vol. 14, no. 1, pp. 67-72, 1999.

[16] H.-M. Oh, S. J. Lee, J.-H. Kim, H.-S. Kim, and B.-D. Yoon, "Seasonal variation and indirect monitoring of microcystin concentrations in Daechung Reservoir, Korea," Applied and Environmental Microbiology, vol. 67, no. 4, pp. 1484-1489, 2001.

[17] S.-H. Joung, J.-H. Kim, C.-Y. Ahn, S.-S. Choi, H.-S. Kim, and H.-M. Oh, "Water quality and cyanobacterial anatoxin-a concentration in Daechung reservoir," Korean Journal of Limnology, vol. 35, no. 4, pp. 257-265, 2002.

[18] M.-Y. Suh, B.-H. Kim, and M.-S. Han, "Distribution of cyanotoxin microcystin-LR in Han River system and ecological park in Seoul and Kyunggi districts," Korean Journal of Limnology, vol. 38, no. 2, pp. 237-248, 2005.

[19] Ministry of Environment, Operational Plan for 2013 Algal Bloom Alert System, Water Quality Management Division, 2012.
[20] K. Sivonen, "Effects of light, temperature, nitrate, orthophosphate, and bacteria on growth of and hepatotoxin production by Oscillatoria agardhii strains," Applied and Environmental Microbiology, vol. 56, no. 9, pp. 2658-2666, 1990.

[21] B. Kim, J.-H. Park, G. Hwang, M.-S. Jun, and K. Choi, "Eutrophication of reservoirs in South Korea," Limnology, vol. 2, no. 3, pp. 223-229, 2001.

[22] M.-W. Kim, M.-H. Kim, J.-C. Cho, and S.-J. Kim, "Changes of biological community by cyanobacterial bloom in Daechung reservoir," Korean Journal of Limnology, vol. 281, no. 69, pp. 1-9, 1995.

[23] H.-M. Oh and D.-H. Kim, "Short-term prediction of the bluegreen algal bloom in Daechung Reservoir," Korean Journal of Limnology, vol. 28, no. 2, pp. 127-135, 1995.

[24] J.-H. Lee, H.-M. Oh, and J. Maeng, "Water quality and phytoplankton standing crops in the Daechung reservoir," Korean Journal of Environmental Biology, vol. 18, no. 3, pp. 355-365, 2000.

[25] J.-K. Shin, K.-J. Cho, and I.-H. Oh, "Dynamics of water environmental factors and phytoplankton in Taechong Reservoir," Korean Journal of Environmental Biology, vol. 17, no. 4, pp. 529$541,1999$.

[26] K.-G. An and J. R. Jones, "Factors regulating bluegreen dominance in a reservoir directly influenced by the Asian monsoon," Hydrobiologia, vol. 432, no. 1-3, pp. 37-48, 2000.

[27] C.-Y. Ahn, H.-S. Kim, B.-D. Yoon, and H.-M. Oh, "Influence of rainfall on cyanobacterial bloom in Daechung reservoir," Korean Journal of Limnology, vol. 36, no. 4, pp. 413-419, 2003.

[28] S.-G. Kim, S.-K. Rhee, C.-Y. Ahn et al., "Determination of cyanobacterial diversity during algal blooms in Daechung Reservoir, Korea, on the basis of $c p c$ BA intergenic spacer region analysis," Applied and Environmental Microbiology, vol. 72, no. 5, pp. 3252-3258, 2006.

[29] S.-G. Kim, S.-H. Joung, C.-Y. Ahn, S.-R. Ko, S. M. Boo, and H.-M. Oh, "Annual variation of Microcystis genotypes and their potential toxicity in water and sediment from a eutrophic reservoir," FEMS Microbiology Ecology, vol. 74, no. 1, pp. 93-102, 2010.

[30] K. Ha, H.-W. Kim, and G.-J. Joo, “The phytoplankton succession in the lower part of hypertrophic Nakdong River (Mulgum), South Korea," Hydrobiologia, vol. 369-370, pp. 217-227, 1998.

[31] K. Ha, M.-H. Jang, and G.-J. Joo, "Spatial and temporal dynamics of phytoplankton communities along a regulated river system, the Nakdong River, Korea," Hydrobiologia, vol. 470, no. 1-3, pp. 235-245, 2002.

[32] K.-S. Jeong, D.-K. Kim, and G.-J. Joo, "Delayed influence of dam storage and discharge on the determination of seasonal proliferations of Microcystis aeruginosa and Stephanodiscus hantzschii in a regulated river system of the lower Nakdong River (South Korea)," Water Research, vol. 41, no. 6, pp. 1269-1279, 2007.

[33] S. W. Jung, O. Y. Kwon, S. M. Yun, H. M. Joo, J.-H. Kang, and J. H. Lee, "Impacts of dam discharge on river environments and phytoplankton communities in a regulated river system, the lower Han River of South Korea," Journal of Ecology and Environment, vol. 37, no. 1, pp. 1-11, 2014.

[34] M. Hur, I. Lee, B.-M. Tak et al., “Temporal shifts in cyanobacterial communities at different sites on the Nakdong River in Korea," Water Research, vol. 47, no. 19, pp. 6973-6982, 2013.

[35] C.-Y. Ahn, S.-H. Joung, C.-S. Park, H.-S. Kim, B.-D. Yoon, and H.-M. Oh, "Comparison of sampling and analytical methods for monitoring of cyanobacteria-dominated surface waters," Hydrobiologia, vol. 596, no. 1, pp. 413-421, 2008. 
[36] S.-H. Joung, C.-J. Kim, C.-Y. Ahn, K.-Y. Jang, M. B. Sung, and H.-M. Oh, "Simple method for a cell count of the colonial cyanobacterium, Microcystis sp," Journal of Microbiology, vol. 44, no. 5, pp. 562-565, 2006.

[37] C.-Y. Ahn, A.-S. Chung, and H.-M. Oh, "Rainfall, phycocyanin, and $\mathrm{N}: \mathrm{P}$ ratios related to cyanobacterial blooms in a Korean large reservoir," Hydrobiologia, vol. 474, no. 1-3, pp. 117-124, 2002.

[38] C.-Y. Ahn, D.-K. Park, H.-S. Kim, A.-S. Chung, and H.-M. Oh, "K:Fe ratio as an indicator of cyanobacterial bloom in a eutrophic lake," Journal of Microbiology and Biotechnology, vol. 14, no. 2, pp. 290-296, 2004.

[39] R. Falconer, "Health problems from exposure to cyanobacteria and proposed safety guidelines for drinking and recreational water," in Detection Methods for Cyanobacterial Toxins, G. A. Codd, T. M. Jefferies, C. W. Keevil, and E. Potter, Eds., pp. 310, The Royal Society of Chemistry, Cambridge, UK, 1994.

[40] World Health Organization (WHO), Guidelines for Drinking Water Quality: Volume 2: Health Criteria and Other Supporting Information, World Health Organization, Geneva, Switzerland, 2nd edition, 1998.

[41] World Health Organization (WHO), "Algae and cyanobacteria in fresh water," in Guidelines for Safe Recreational Water Environments; Coastal and Freshwaters, vol. 1, pp. 136-158, World Health Organization (WHO), Geneva, Switzerland, 2003.

[42] NHMRC and NRMMC, Australian Drinking Water Guidelines, National Health and Medical Research Council, Canberra, Australia, 2011.

[43] C.-Y. Ahn, S.-H. Joung, S.-K. Yoon, and H.-M. Oh, "Alternative alert system for cyanobacterial bloom, using phycocyanin as a level determinant," Journal of Microbiology, vol. 45, no. 2, pp. 98-104, 2007.

[44] H.-K. Park, H. Kim, J. J. Lee et al., "Investigation of criterion on harmful algae alert system using correlation between cell numbers and cellular microcystins content of Korean toxic cyanobacteria," Journal of Korean Society on Water Quality, vol. 27, no. 4, pp. 491-498, 2011.

[45] C. S. Reynolds, The Ecology of Freshwater Phytoplankton, Cambridge University Press, Cambridge, UK, 1984.

[46] F. Recknagel, M. French, P. Harkonen, and K.-I. Yabunaka, "Artificial neural network approach for modelling and prediction of algal blooms," Ecological Modelling, vol. 96, no. 1-3, pp. 11-28, 1997.

[47] H. Wilson and F. Recknagel, “Towards a generic artificial neural network model for dynamic predictions of algal abundance in freshwater lakes," Ecological Modelling, vol. 146, no. 1, pp. 69-84, 2001.

[48] B. Guven and A. Howard, "Modelling the growth and movement of cyanobacteria in river systems," Science of the Total Environment, vol. 368, no. 2-3, pp. 898-908, 2006.

[49] H.-M. Oh, C.-Y. Ahn, J.-W. Lee, T.-S. Chon, K. H. Choi, and Y.-S. Park, "Community patterning and identification of predominant factors in algal bloom in Daechung Reservoir (Korea) using artificial neural networks," Ecological Modelling, vol. 203, no. 1-2, pp. 109-118, 2007.

[50] C.-Y. Ahn, H.-M. Oh, and Y.-S. Park, "Evaluation of environmental factors on cyanobacterial bloom in eutrophic reservoir using artificial neural networks," Journal of Phycology, vol. 47, no. 3, pp. 495-504, 2011.

[51] K.-S. Jeong, F. Recknagel, and G.-J. Joo, "Prediction and elucidation of population dynamics of the blue-green algae Microcystis aeruginosa and Stephanodiscus hantzschii in the Nakdong RiverReservoir System (South Korea) by artificial neural networks," in Ecological Informatics: Understanding Ecology by BiologicallyInspired Computation, F. Recknagel, Ed., pp. 196-213, Springer, Berlin, Germany, 2003.

[52] S. S. Park and Y. S. Lee, "A water quality modeling study of the Nakdong River, Korea," Ecological Modelling, vol. 152, no. 1, pp. 65-75, 2002.

[53] K.-S. Jeong, D.-K. Kim, P. Whigham, and G.-J. Joo, "Modelling Microcystis aeruginosa bloom dynamics in the Nakdong River by means of evolutionary computation and statistical approach," Ecological Modelling, vol. 161, no. 1-2, pp. 63-75, 2003.

[54] D.-K. Kim, H. Cao, K.-S. Jeong, F. Recknagel, and G.-J. Joo, "Predictive function and rules for population dynamics of Microcystis aeruginosa in the regulated Nakdong River (South Korea), discovered by evolutionary algorithms," Ecological Modelling, vol. 203, no. 1-2, pp. 147-156, 2007.

[55] K.-S. Jeong, D.-G. Hong, M.-S. Byeon et al., "Stream modification patterns in a river basin: field survey and self-organizing map (SOM) application," Ecological Informatics, vol. 5, no. 4, pp. 293-303, 2010. 

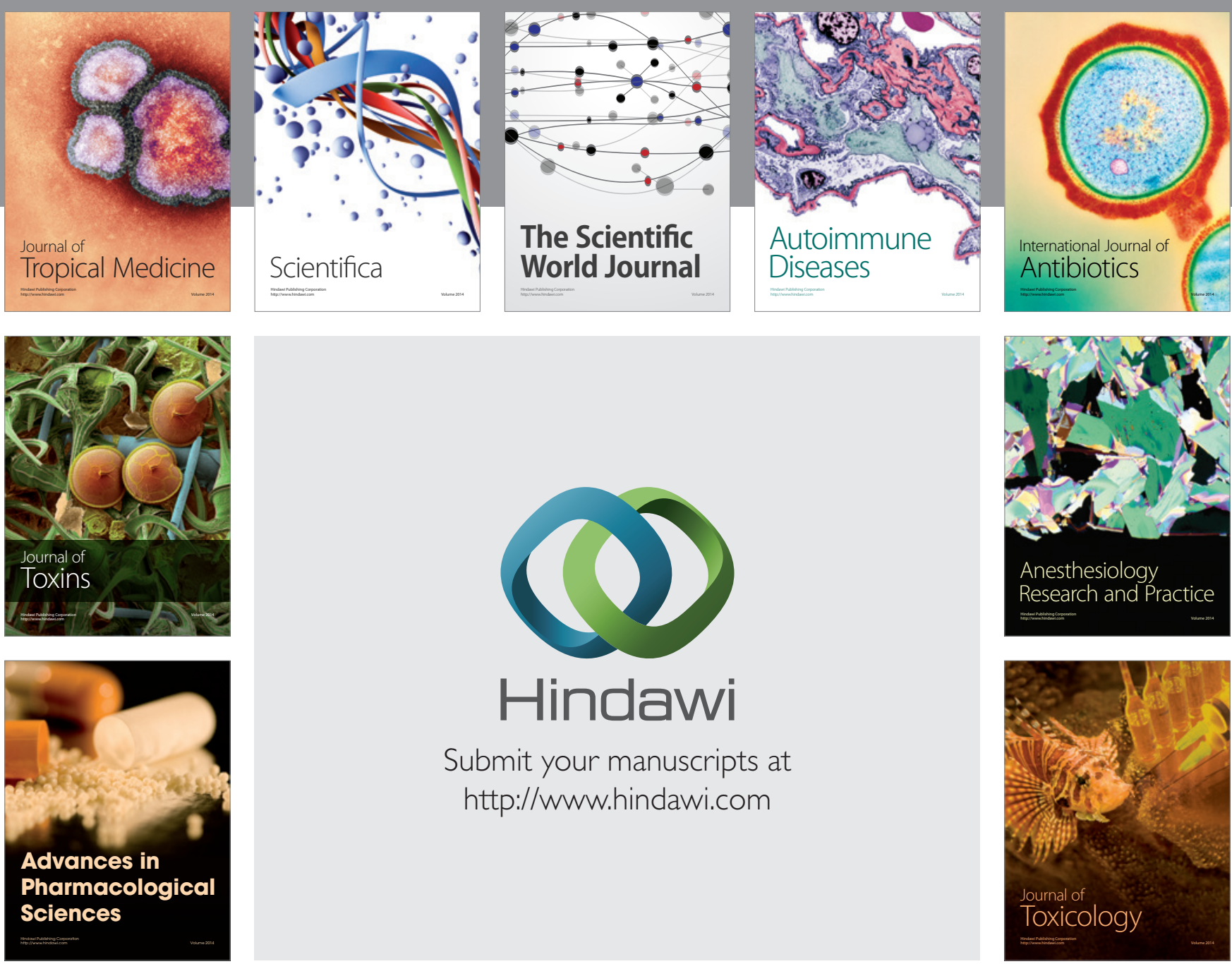

\section{Hindawi}

Submit your manuscripts at

http://www.hindawi.com
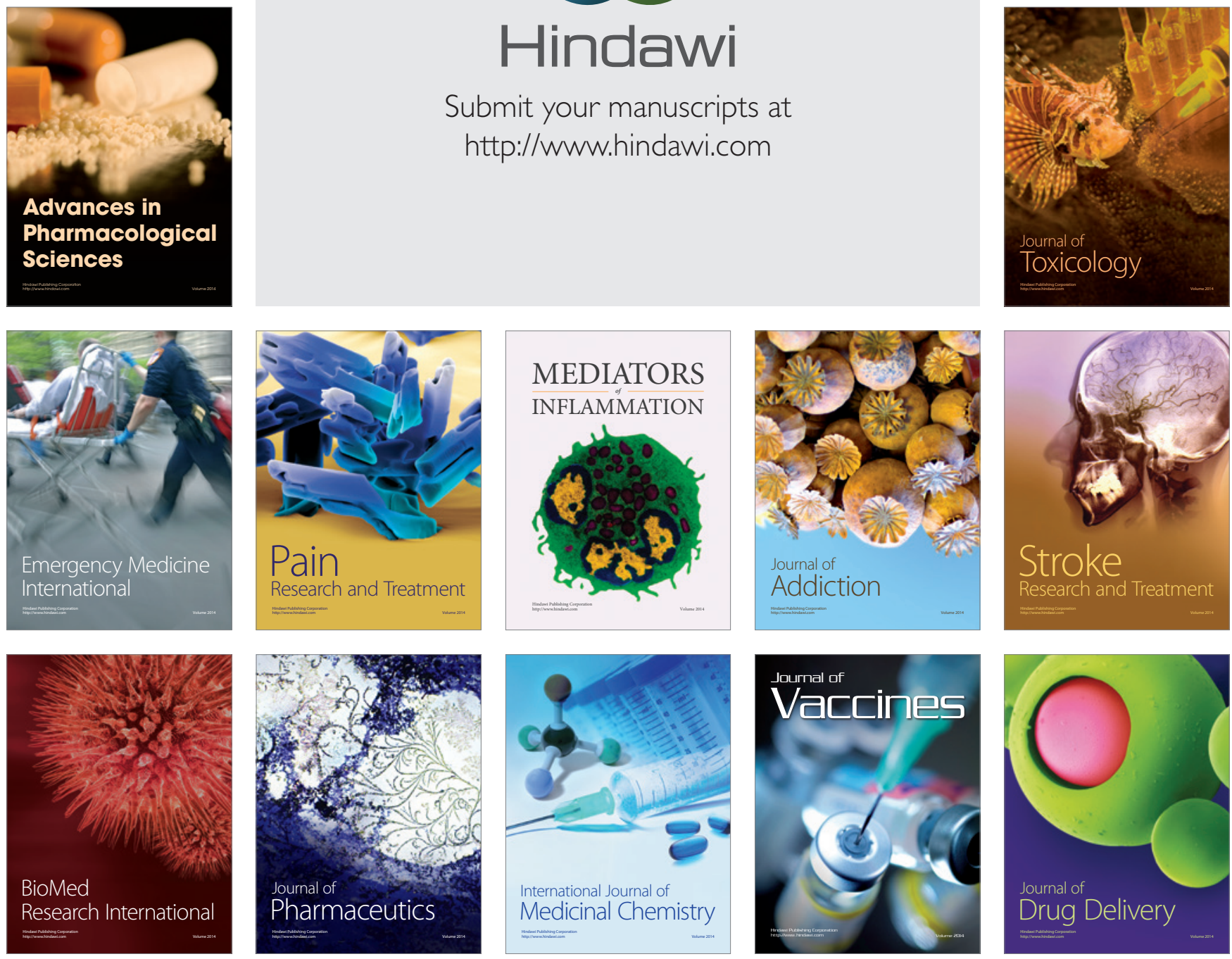